\title{
Synthesis of low-cost porous ceramic microspheres from waste gangue for dye adsorption
}

\author{
Shu YAN ${ }^{a}$, Yiming $\mathrm{PAN}^{b}, \mathrm{Lu} \mathrm{WANG}^{a}$, Jingjing $\mathrm{LIU}^{a}$, Zaijuan ZHANG ${ }^{a}$, \\ Wenlong $\mathrm{HUO}^{a}$, Jinlong YANG ${ }^{a, b,}$, Yong $\mathrm{HUANG}^{a}$ \\ ${ }^{a}$ State Key Laboratory of New Ceramics and Fine Processing, School of Materials \\ Science and Engineering, Tsinghua University, Beijing 100084, China \\ ${ }^{b}$ School of Materials Science and Engineering, Dalian Jiaotong University, Dalian 116028, Liaoning, China
}

Received: July 14, 2017; Revised: October 15, 2017; Accepted: October 27, 2017

(C) The Author(s) 2017. This article is published with open access at Springerlink.com

\begin{abstract}
Low-cost porous ceramic microspheres from waste gangue were prepared by simple spray drying and subsequent calcination. Effects of calcination temperature on phase and microstructure evolution, specific surface area, pore structure, and dye adsorption mechanism of the microspheres were investigated systematically. Results showed that the microspheres were spherical, with some mesopores both on the surface and inside the spheres. The phase kept kaolinite after calcined at 800 and $900{ }^{\circ} \mathrm{C}$ and transformed into mullite at $1000{ }^{\circ} \mathrm{C}$. The microspheres calcined at $800{ }^{\circ} \mathrm{C}$ showed larger adsorption capacity and removal efficiency than those calcined at higher temperatures. Methylene blue (MB) and basic fuchsin (BF) removal efficiency reached 100\% and $99.9 \%$ with the microsphere dosage of $20 \mathrm{~g} / \mathrm{L}$, respectively, which was comparable to that of other low-cost waste adsorbents used to remove dyes in the literature. Adsorption kinetics data followed the pseudosecond-order kinetic model, and the isotherm data fit the Langmuir isotherm model. The adsorption process was attributed to multiple adsorption mechanisms including physical adsorption, hydrogen bonding, and electrostatic interactions between dyes and gangue microspheres. The low-cost porous microspheres with excellent cyclic regeneration properties are promising absorbent for dyes in wastewater filtration and adsorption treatment.
\end{abstract}

Keywords: adsorption; microspheres; calcination; microstructure; equilibrium

\section{Introduction}

Ceramic microspheres have attracted a lot of attention for various applications due to their small size (0.01$1.0 \mathrm{~mm}$ ), light weight, low heat conductivity, and high dispersion [1-4]. Currently, much work has been done on the synthesis of microspheres including spray drying

* Corresponding author.

E-mail: jlyang@mail.tsinghua.edu.cn method [3,5,6], sol-gel method [7,8], and template method [9,10]. Leib et al. [7] produced zirconia microparticles by sol-gel method and significantly improved the thermal stability of the got particles by yttria doping.

Schmitt et al. [8] produced hollow glass microspheres by sol-gel method using derived sodium borosilicate glass with numerous small bubbles. Sun et al. [9] reported carbonaceous polysaccharide microspheres as templates to prepare a series of metal oxide spheres, such as $\mathrm{SnO}_{2}, \mathrm{Al}_{2} \mathrm{O}_{3}, \mathrm{Ga}_{2} \mathrm{O}_{3}$, etc. Noh et al. [10] prepared 
thermally stable $\mathrm{SiC}$ hollow spheres using $\mathrm{SiO}_{2}$ templates at $1300{ }^{\circ} \mathrm{C}$. Although the mentioned methods could obtain microspheres with certain contents successfully, the composition of raw material is fixed and much expensive, which limits its mass production and widely applications.

Qu et al. [11] fabricated high-strength glass foams with spheres by spray drying method. Qi et al. [12] developed hollow sphere ceramics (HSCs) with porosity decreased from $59 \%$ to $42 \%$ when the sintering temperature was $1400-1600{ }^{\circ} \mathrm{C}$. Consequently, the spray drying method was applied to fabricate glass foams and hollow sphere ceramics, which was considered to be prospective, low-cost, and widely used in industrial applications.

Coal gangue is a typical solid waste pollution generated during mining process [13-15]. The accumulation of coal gangue occupies land, pollutes air, causes serious environmental problems, and damages people's health [13-15]. Thus, the management and utilization of coal gangue are an urgent problem to be solved. Coal gangue has a mass of kaolinite with layered silicate mineral consisted of siloxane- and gibbsite-like layers $[13,16]$. Nowadays, the chemical activation, mechanical activation, and thermal activation are effective ways to improve the activation of coal gangue $[13,17]$. After thermal activation at $700{ }^{\circ} \mathrm{C}$, the contents of $\mathrm{Al}_{2} \mathrm{O}_{3}$ and $\mathrm{SiO}_{2}$ in coal gangue increased to $92.31 \%$ and $64.44 \%$, respectively [13]. After mechanical grinding, the specific surface area of coal gangue increased from 0.41 to $8.66 \mathrm{~m}^{2} / \mathrm{g}$ [17]. Jabłońska et al. [14] compared surface properties of different kinds of modified coal gangue. Results showed that BET surface area of coal gangue modified with $\mathrm{H}_{2} \mathrm{NO}_{3}$ and $\mathrm{H}_{2} \mathrm{O}_{2}$ increased from 7.36 to $8.12 \mathrm{~m}^{2} / \mathrm{g}$. Total pore volume and average pore size of the samples also increased, which were attributed to the increased adsorption space. The space of thermal modification at 250 and $600{ }^{\circ} \mathrm{C}$ was $25 \%\left(15.42 \mathrm{~mm}^{3} / \mathrm{g}\right)$ and $120 \%$ $\left(27.26 \mathrm{~mm}^{3} / \mathrm{g}\right)$, respectively.

Usually, coal gangue was used as raw material to produce zeolite and mullite ceramics [18-20]. Moreover, many investigations have focused on its promising adsorption property in polluted water, especially for heavy ions and organic dyes [21-24]. Qiu and Cheng [21] modified the coal gangue with sodium tetraborate $\left(\mathrm{Na}_{2} \mathrm{~B}_{4} \mathrm{O}_{7} \cdot 10 \mathrm{H}_{2} \mathrm{O}\right)$ during calcination process to improve its removal efficiency of $\mathrm{Mn}^{2+}$, which was due to the increase of pore volume (from 0.021 to $0.067 \mathrm{~cm}^{3} / \mathrm{g}$ ) and specific surface area (from 9.29 to $20.05 \mathrm{~m}^{2} / \mathrm{g}$ ) for raw coal gangue. The decomposition of carbonate minerals and dehydration of coal gangue particles by addition of sodium tetraborate during calcination were originated from the generation of porous structure and large specific surface area. Based on the experiment data, the pseudo-second-order kinetic model could describe the adsorption process. Unuabonah et al. [23] modified the surface of kaolinite with strong presence of inner $-\mathrm{OH}$ functional group by sodium tetraborate. The modification process increases both the adsorption rate and capacity of aniline blue from 1666.67 to 2000 $\mathrm{mg} / \mathrm{kg}$. Khan et al. [24] provided that the iron-manganese oxide coated kaolinite could adsorb the basic fuchsin (BF) and crystal violet (CV) dyes from aqueous solution. The Langmuir saturation adsorption capacity of BF and CV was 10.36 and $20.64 \mathrm{mg} / \mathrm{g}$, respectively.

Nevertheless, most effective adsorbents such as activated carbon and nanospheres were expensive $[25,26]$. The modified coal gangue showed potential for sewage treatment, but the adsorption performance of gangue was limited by its specific surface area. Combining the adsorption characteristics of gangue powder with special structure of cenosphere, preparation of coal gangue microspheres by an easy method is considered to be a proper way. Therefore, it is of great importance to develop a novel and low-cost absorbent with high removal efficiency as soon as possible.

In the present work, we described novel low-cost porous microspheres from gangue using spray drying method and thereafter systematically characterized the effects of calcination temperature on initial products using phase evolution, pore structure, micrographs, functional groups, and adsorption properties of $\mathrm{MB}$ and $\mathrm{BF}$ solutions.

\section{Experimental}

\section{1 Materials and experiments}

The raw material was coal gangue powder (Yonglong Bangda New Materials Co., Ltd., China). The green gangue microspheres were prepared by spray drying method, as shown in Fig. 1 [5,6].

Firstly, the slurry containing coal gangue powder, water, and polyvinyl formal adhesive (10 wt $\%$ based on powder, named "107 building glue", major components were polyvinyl alcohol and methyl 


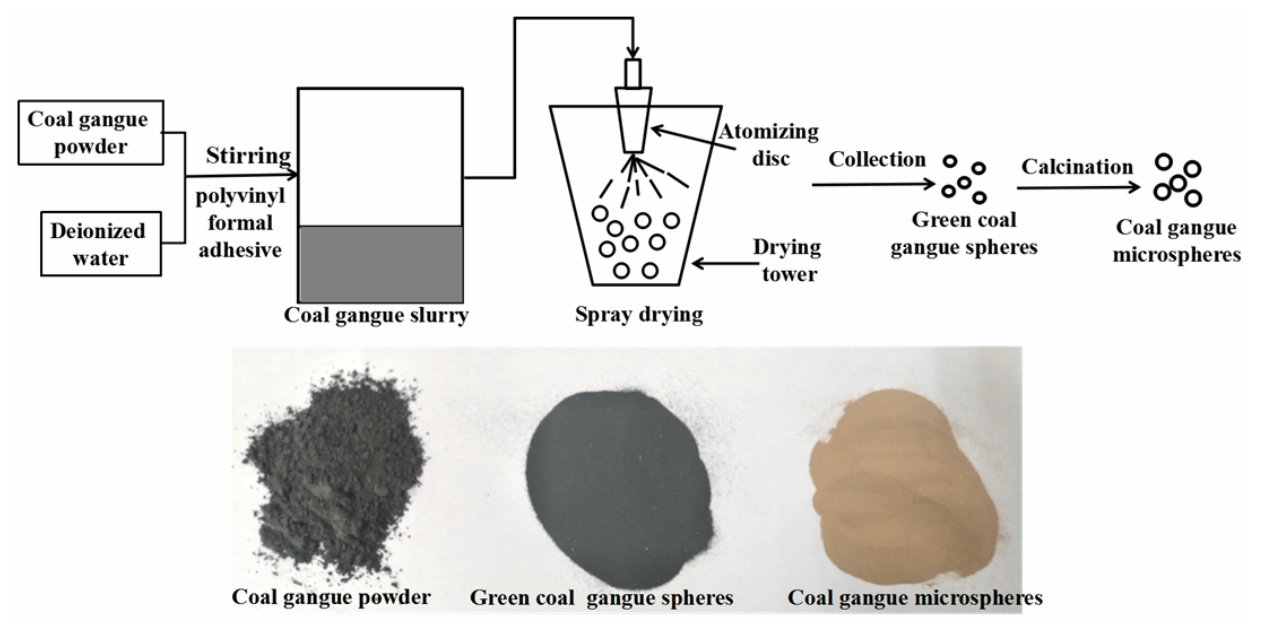

Fig. 1 Scheme of the preparation of coal gangue microspheres.

methacrylate, $\mathrm{pH}=7$ ) was ball-milled for $10 \mathrm{~h}$ to obtain a homogeneous slurry with a solid loading of 50 $w t \%$. Continually, the slurry was prepared with vigorous stirring. The slurry was introduced into a centrifugal atomization equipment to atomize it into slurry droplets which were fed into a drying chamber at $200{ }^{\circ} \mathrm{C}$. Finally, green coal gangue spheres were collected after spray drying. Figure 2 displays morphologies of raw coal gangue and green microspheres. Coal gangue in Fig. 2(a) exhibits fine powder shape in the size of $\sim 2 \mu \mathrm{m}$, and green microspheres in Fig. 2(b) have the average diameter of $\sim 55 \mu \mathrm{m}$. As shown in Fig. 2(c), the microsphere surfaces are made of uniform raw powder. The composition of the obtained coal gangue powder is presented in Table 1.

Then, the green microspheres were performed in a muffle furnace and treated at 800,900 , and $1000{ }^{\circ} \mathrm{C}$ for $1 \mathrm{~h}$ in air with a heating rate of $5{ }^{\circ} \mathrm{C} / \mathrm{min}$ to obtain the

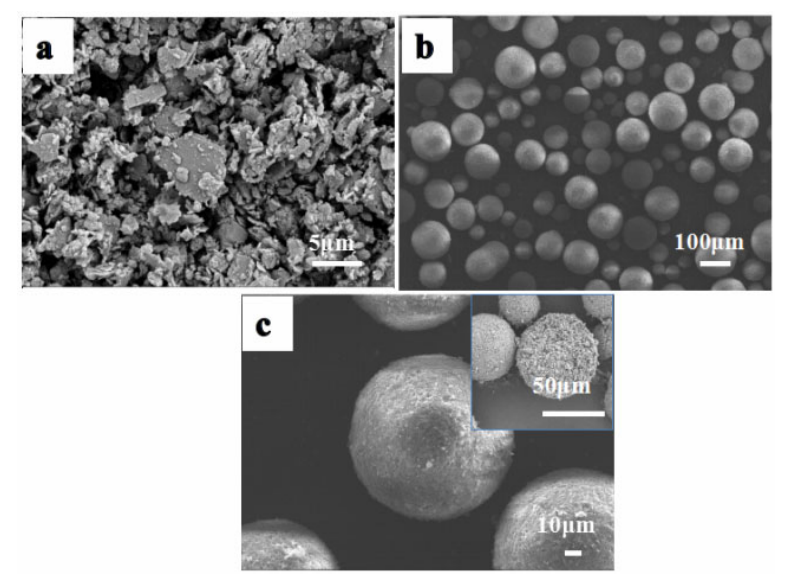

Fig. 2 SEM images and particle size distribution of raw coal gangue and green microspheres: (a) raw coal gangue, $(b, c)$ green spheres.
Table 1 Element compositions of raw coal gangue powder

\begin{tabular}{cccccccccc}
\hline Coal gangue & $\mathrm{O}$ & $\mathrm{Si}$ & $\mathrm{C}$ & $\mathrm{Al}$ & $\mathrm{Fe}$ & $\mathrm{K}$ & $\mathrm{Ca}$ & $\mathrm{S}$ & Other \\
\hline Mass fraction (wt\%) & 27.57 & 26.13 & 19.12 & 14.28 & 5.40 & 2.36 & 1.69 & 0.968 & 2.48
\end{tabular}

gangue microspheres. Then, the samples were cooled in the furnace to room temperature for use.

\section{2 Characterization}

The chemical composition of the raw coal gangue powder was determined by X-ray fluorescence spectrometer (XRF-1800, Shi-madzu, Japan). Thermal gravimetric (TG) analysis and differential thermal analysis (DTA) (Netzsch STA449F3, Germany) of green gangue microspheres were carried out in an air atmosphere in alumina crucibles over a temperature ranging from 20 to $1200{ }^{\circ} \mathrm{C}$ at $10{ }^{\circ} \mathrm{C} / \mathrm{min}$. The true density of microspheres was measured via a nitrogen replacement method (G-Denpyc 2900, Gold APP Instrument Corporation, China). The packing density was calculated by weighting a certain volume of microspheres in a graduated cylinder. The particle size of microspheres was analyzed by laser particle analyzer (Mastersizer 2000, Malvern Instruments, UK). The nitrogen adsorption-desorption measurement was tested on a Gemini VII 2390 (Mike, USA). Phase compositions of the microspheres before and after calcination were examined by X-ray diffraction (XRD, D8ADVANCE, Bruker, Karlsruhe, Germany). Microstructure of the samples was performed by scanning electron microscope (SEM, SSX-550, Shimadzu, Kyoto, Japan).

\section{3 Adsorption studies}

Adsorption properties were carried out using $100 \mathrm{~mL}$ 
Erlenmeyer flasks with the same volume of $50 \mathrm{~mL}$. The concentration of methylene blue (MB) and basic fuchsin (BF) was $100 \mathrm{mg} / \mathrm{L}$. In order to investigate the effects of calcination temperature and the dosage of the gangue microspheres, different dosages of calcined microspheres were added into the MB and BF solutions to achieve liquid-solid ratios by $1-50 \mathrm{~g} / \mathrm{L}$. The samples were placed in an oscillating shaker operated at $140 \mathrm{rpm}$ and $30{ }^{\circ} \mathrm{C}$ to keep adsorption equilibrium for $10 \mathrm{~h}$. After centrifugation, the concentration of MB and BF solutions was determined using a UV-Vis spectrophotometer at wavelength of 664 and $544 \mathrm{~nm}$, respectively. The adsorption capacity and removal efficiency of MB and BF were calculated using Eqs. (1) and (2), respectively, which are listed as follows:

$$
\begin{aligned}
& \operatorname{Adsorption} \text { capacity }(q, \mathrm{mg} / \mathrm{g})=\frac{\left(c_{0}-c_{\mathrm{e}}\right) \times V}{m} \\
& \text { Removal efficiency }(\%)=\frac{\left(c_{0}-c_{\mathrm{e}}\right)}{c_{0}} \times 100 \%
\end{aligned}
$$

where $c_{0}(\mathrm{mg} / \mathrm{L})$ is the initial $\mathrm{MB}$ and $\mathrm{BF}$ concentration, $c_{\mathrm{e}}(\mathrm{mg} / \mathrm{L})$ is the equilibrium concentration, $V$ (L) is the volume of the dye solution, and $m(\mathrm{~g})$ is the weight of adsorbent.

Based on the above parameters, in order to investigate the adsorption isotherm, certain amount $(10 \mathrm{~g} / \mathrm{L})$ of microspheres was added to the $100 \mathrm{~mL}$ Erlenmeyer flask with $50 \mathrm{~mL} \mathrm{MB}$ and $\mathrm{BF}$ solution, achieving a certain initial concentration of $80-400 \mathrm{mg} / \mathrm{L}$. The experiments were also performed at $30{ }^{\circ} \mathrm{C}$. In order to investigate the adsorption kinetics of the microspheres in $\mathrm{MB}$ and $\mathrm{BF}$ solution, certain amount $(10 \mathrm{~g} / \mathrm{L})$ of adsorbents was added to the $100 \mathrm{~mL}$ Erlenmeyer flask with $50 \mathrm{~mL}$ dye solution. The pre-determined time adsorption capacity and removal efficiency were also calculated by Eqs. (1) and (2) at time $t$.

\section{Results and discussion}

\section{1 Phase and chemical bands of microspheres}

Figure 3 presents the TG/DTA curves of the green gangue microspheres under air atmosphere, heating up to $1200{ }^{\circ} \mathrm{C}$ with rate of $10{ }^{\circ} \mathrm{C} / \mathrm{min}$. The TG curve of the green gangue microspheres showed that the major mass loss before $1100{ }^{\circ} \mathrm{C}$ was $\sim 13 \mathrm{wt} \%$, which was due to the evaporation of free water, decomposition of minerals, and combustion of carbon and organic matters $[13,17]$. As for the DTA curve, the endothermic peak

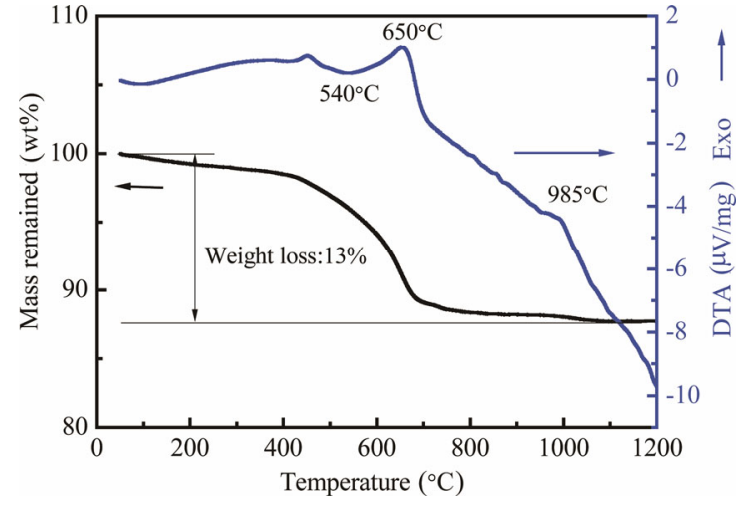

Fig. 3 TG/DTA curves of green coal gangue microspheres in air atmosphere with heating rate of $10{ }^{\circ} \mathrm{C} / \mathrm{min}$ up to $1200{ }^{\circ} \mathrm{C}$.

presented at $540{ }^{\circ} \mathrm{C}$ was contributed by the dehydration of $-\mathrm{OH}$ groups of kaolinite and formation of metakaolin, as described by the following reaction:

$$
\mathrm{Al}_{2} \mathrm{O}_{3} \cdot 2 \mathrm{SiO}_{2} \cdot 2 \mathrm{H}_{2} \mathrm{O} \rightarrow \mathrm{Al}_{2} \mathrm{O}_{3} \cdot 2 \mathrm{SiO}_{2}+2 \mathrm{H}_{2} \mathrm{O}(\mathrm{g})
$$

The exothermic peak at $650{ }^{\circ} \mathrm{C}$ was caused by combustion of carbon and organics [13,17]. Thus, it provided that higher temperature was needed to remove the carbonaceous minerals. The reaction could be presented by the following chemical equations [17,27]:

$$
\begin{aligned}
\mathrm{C}+\mathrm{O}_{2} & \rightarrow \mathrm{CO}_{2} \\
\mathrm{C}_{m} \mathrm{H}_{n}+(2 m+1 / 2) \mathrm{O}_{2} & \rightarrow \mathrm{C}_{m} \mathrm{CO}_{2}+n / 2 \mathrm{H}_{2} \mathrm{O}
\end{aligned}
$$

The DTA curve exhibited exotherm $\left(985{ }^{\circ} \mathrm{C}\right)$ centered between 950 and $1000{ }^{\circ} \mathrm{C}$, which was due to the transformation of metakaolin into mullite $\left(3 \mathrm{Al}_{2} \mathrm{O}_{3} \cdot 2 \mathrm{SiO}_{2}\right)$ [17], as could be described by the following equation:

$$
3\left(\mathrm{Al}_{2} \mathrm{O}_{3} \cdot 2 \mathrm{SiO}_{2}\right) \rightarrow 3 \mathrm{Al}_{2} \mathrm{O}_{3} \cdot 2 \mathrm{SiO}_{2}+4 \mathrm{SiO}_{2}
$$

There were no obvious additional peaks of adhesion agent of the microspheres, which was due to their small content. Considering the TG results, the thermal evolution of the gangue microspheres showed similar tendency to ordinary coal gangue during calcining.

Figure 4 displayed XRD patterns of coal gangue microspheres before and after calcined at different temperatures for $1 \mathrm{~h}$. As can be seen, kaolinite and $\alpha$-quartz were the two major phases in uncalcined coal gangue microspheres [17,28]. It also contained some geothite and mica. The phase of the microspheres was not changed obviously after calcined at 800 and $900{ }^{\circ} \mathrm{C}$ for $1 \mathrm{~h}$. After treated at $1000{ }^{\circ} \mathrm{C}$, some mullite phase has been formed, whereas several sharp $\alpha$-quartz peaks were still observed, which were introduced from raw coal gangue.

Figure 5 shows the FT-IR spectra of the coal gangue microspheres before and after calcination. As for the 


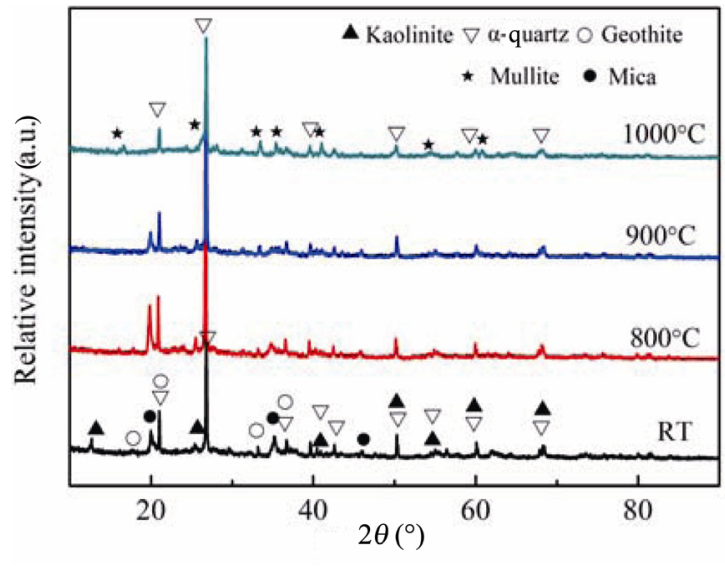

Fig. 4 XRD patterns of the coal gangue microspheres before and after high temperature treatment.

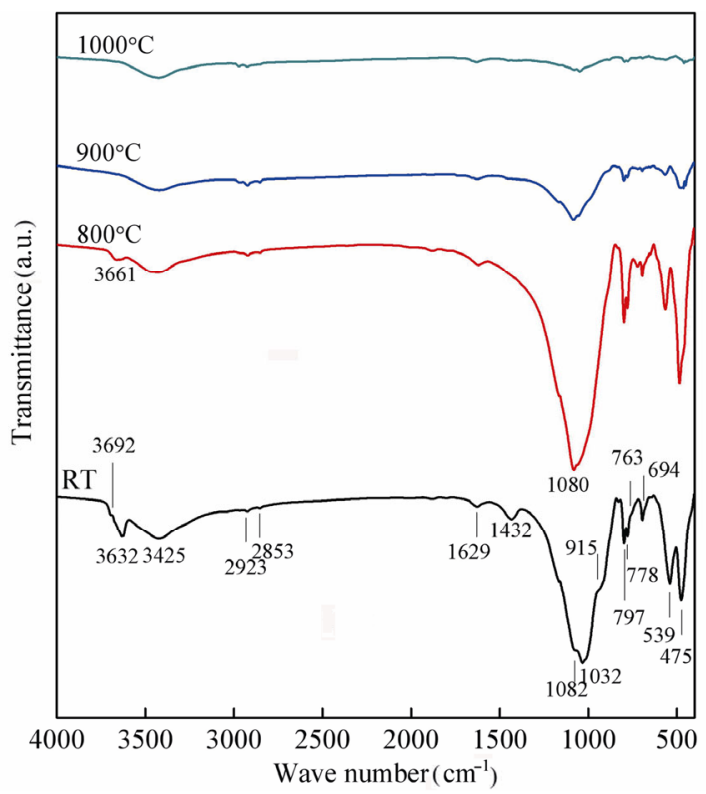

Fig. 5 FT-IR spectra of the coal gangue microspheres before and after high temperature treatment.

untreated samples in Fig. 5, the bands at 3692, 3661, and $3632 \mathrm{~cm}^{-1}$ were associated with $\mathrm{O}-\mathrm{H}$ in kaolinite structure $[29,30]$. The IR bands at 1032, 797, 778, and $475 \mathrm{~cm}^{-1}$ were related to $\mathrm{Si}-\mathrm{O}-\mathrm{Si}$. The bands located at 915 and $539 \mathrm{~cm}^{-1}$ were attributed to Al-OH vibration and $\mathrm{Si}-\mathrm{O}-\mathrm{Al}$, respectively $[29,30]$. The bands at 1100 , 810 , and $694 \mathrm{~cm}^{-1}$ were corresponded to $\mathrm{Si}-\mathrm{O}$. The bands at 2923 and $2853 \mathrm{~cm}^{-1}$ were assigned to aliphatic or naphthenic $\mathrm{C}-\mathrm{H}$, which were introduced by the carbonaceous components in gangue [13]. After calcined at higher than $800{ }^{\circ} \mathrm{C}$, the bands at 3695 and $3632 \mathrm{~cm}^{-1}$ were deceased and changed to $3661 \mathrm{~cm}^{-1}$, which indicated most of the hydroxyl groups on kaolinite have been removed. It is because of the depolymerization of silica tetrahedrons induced by thermal treatment [13,
$29,30]$. The intensity of the bands at 1082 and $1032 \mathrm{~cm}^{-1}$ was also decreased as the temperature increased; the bands became wide at $1000{ }^{\circ} \mathrm{C}$, which was due to the depolymerization and collapse of silica tetrahedrons structure in the gangue $[13,17,29,30]$. Many different functional groups on the surface of microspheres were beneficial to enhance adsorption properties.

\section{2 Microstructure analysis of microspheres}

The typical microstructures of gangue microspheres after calcined are shown in Figs. 6 and 7. After treated, the obtained microspheres were still spherical, with some small pores on the surface. From the cross sections in Fig. 7, we observed the inner of the
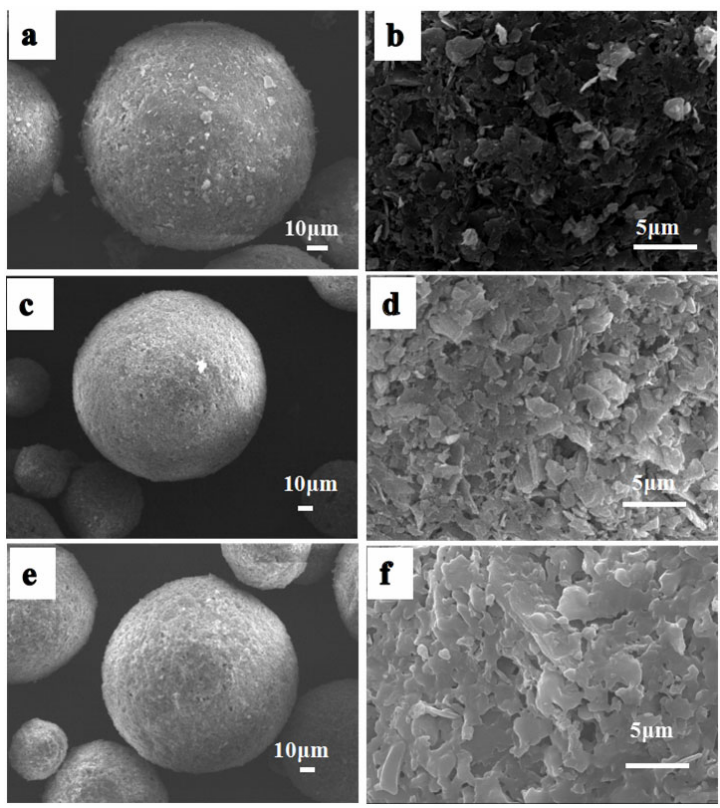

Fig. 6 Typical microstructure of coal gangue microspheres after high temperature treatment at different temperature: (a, b) $800{ }^{\circ} \mathrm{C},(\mathrm{c}, \mathrm{d}) 900{ }^{\circ} \mathrm{C}$ and $(\mathrm{e}, \mathrm{f}) 1000{ }^{\circ} \mathrm{C}$.

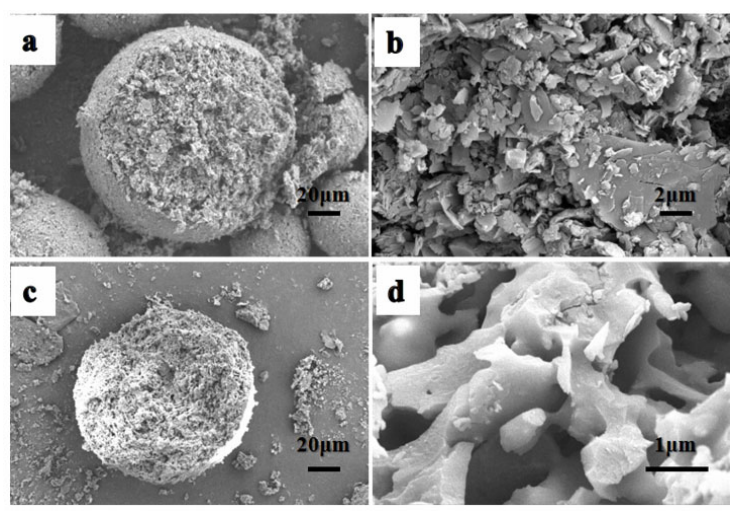

Fig. 7 Cross sections of coal gangue microspheres after treated at $(\mathrm{a}, \mathrm{b}) 800{ }^{\circ} \mathrm{C}$ and $(\mathrm{c}, \mathrm{d}) 1000{ }^{\circ} \mathrm{C}$. 
microspheres kept lamellar structure of kaolin with bigger holes in the middle.

The specific surface areas and porous parameters of the microspheres are shown in Fig. 8 and Table 2. The nitrogen adsorption-desorption isotherms of the samples were classified a typical type IV isotherm characteristic [14,31]. The mesopores on microspheres resulted in hysteresis loops at the $P / P_{0}$ ranges of $0.8-1.0$ [31]. The hysteresis loops decreased as the calcination temperature increased, gradually. The BET specific surface area of the microspheres calcined at $800{ }^{\circ} \mathrm{C}$ was $11.98 \mathrm{~m}^{2} / \mathrm{g}$, and decreased to 6.47 and $1.46 \mathrm{~m}^{2} / \mathrm{g}$ when treated at 900 and $1000{ }^{\circ} \mathrm{C}$, respectively. The average pore diameter from $\mathrm{BJH}$ pore-size distribution pattern was $12.89,12.69$, and $6.15 \mathrm{~nm}$, respectively, indicating the type of mesopores. The decrease was due to recrystallization of kaolinite and mullite [32]. The external surface areas and micropore volumes (Table 2) were calculated by using t-plot method. For the microspheres treated at $800{ }^{\circ} \mathrm{C}$, a total pore volume of $0.04 \mathrm{~cm}^{3} / \mathrm{g}$ was measured, with a micropore area of $0.99 \mathrm{~m}^{2} / \mathrm{g}$ and a larger external surface area of $10.99 \mathrm{~m}^{2} / \mathrm{g}$, as determined by the t-plot method. As inferred from Figs. 6 and 7, the major contribution to specific surface area of the spheres was originated from the external surface of mesoporosity. The surface area decreased at higher calcined temperature. The pore size distribution (Fig. 8(b)) further shows the presence of mesopore characteristic for samples, with pore width between 10 and $90 \mathrm{~nm}$. Thus, the microspheres had porous structure and large specific surface areas, which was beneficial for adsorption and removal of dyes.

\section{3 Adsorption studies}

\subsubsection{Effects of parameters on dye adsorption}

Figure 9 shows the photographs of $\mathrm{MB}$ and $\mathrm{BF}$ solutions adsorbed using different microsphere dosages calcined at $800{ }^{\circ} \mathrm{C}$. The color variation of the solutions became lighter with the microsphere dosage increasing from 1 to $50 \mathrm{~g} / \mathrm{L}$. The solutions turned colorless when the dosage was $50 \mathrm{~g} / \mathrm{L}$, indicating that the microsphere has obvious influence on the adsorption of the dyes under water. Figure 10 shows the effects of calcination temperature, adsorbent dosage, and contact time on the adsorption capacity and removal efficiency of $\mathrm{MB}$ and $\mathrm{BF}$. The calcination temperature of the gangue microspheres has a great influence on the $\mathrm{MB}$ and $\mathrm{BF}$ adsorption. As for the two dyes, the microspheres calcined at $800{ }^{\circ} \mathrm{C}$ presented more adsorption capacity and better removal efficiency than the ones calcined at higher temperatures $\left(900\right.$ and $\left.1000{ }^{\circ} \mathrm{C}\right)$. As for the MB, when the dosage of microspheres ranged from 1 to $10 \mathrm{~g} / \mathrm{L}$, the adsorption capacity decreased sharply from 37.06 $\left(800{ }^{\circ} \mathrm{C}\right), 29.01\left(900{ }^{\circ} \mathrm{C}\right)$, and $21.99 \mathrm{mg} / \mathrm{g}\left(1000{ }^{\circ} \mathrm{C}\right)$ to $10.00\left(800{ }^{\circ} \mathrm{C}\right), 10.00\left(900{ }^{\circ} \mathrm{C}\right)$, and $8.63 \mathrm{mg} / \mathrm{g}\left(1000{ }^{\circ} \mathrm{C}\right)$,

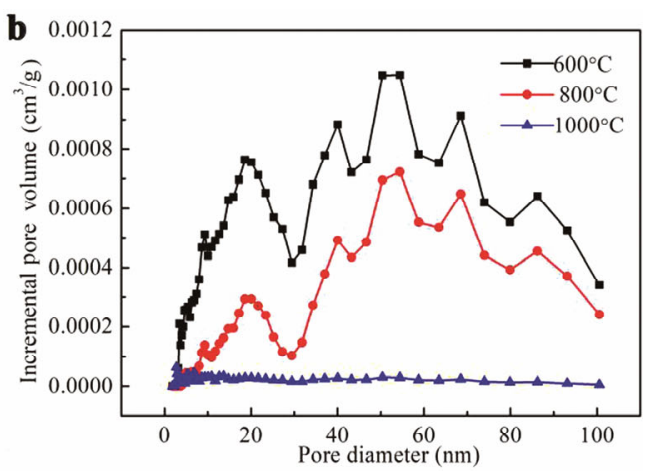

Fig. 8 (a) Nitrogen adsorption-desorption isotherm and (b) corresponding pore size distributions of coal gangue microspheres after calcined at different temperatures.

Table 2 Particle size, density, and porous parameters of gangue microspheres

\begin{tabular}{|c|c|c|c|c|c|c|c|c|c|c|}
\hline Sample & $\begin{array}{c}D_{0.5} \\
(\mu \mathrm{m})\end{array}$ & $\begin{array}{l}\text { True density } \\
\qquad\left(\mathrm{g} / \mathrm{cm}^{3}\right)\end{array}$ & $\begin{array}{c}\text { Bulk } \\
\text { density } \\
\left(\mathrm{g} / \mathrm{cm}^{3}\right)\end{array}$ & $\begin{array}{c}\text { BET } \\
\text { surface area } \\
\left(\mathrm{m}^{2} / \mathrm{g}\right)\end{array}$ & $\begin{array}{c}\text { BJH } \\
\text { pore } \\
\text { diameter }(n m)\end{array}$ & $\begin{array}{c}\text { Micropore } \\
\text { surface area } \\
\left(\mathrm{m}^{2} / \mathrm{g}\right)\end{array}$ & $\begin{array}{c}\text { External } \\
\text { surface area } \\
\left(\mathrm{m}^{2} / \mathrm{g}\right)\end{array}$ & $\begin{array}{l}\text { Total pore } \\
\text { volume } \\
\left(\mathrm{cm}^{3} / \mathrm{g}\right)\end{array}$ & $\begin{array}{c}\text { Micropore } \\
\text { volume } \\
\left(\mathrm{cm}^{3} / \mathrm{g}\right)\end{array}$ & $\begin{array}{c}\text { Mesopore } \\
\text { volume } \\
\left(\mathrm{cm}^{3} / \mathrm{g}\right)\end{array}$ \\
\hline $800{ }^{\circ} \mathrm{C}$ & 17.95 & 2.89 & 0.63 & 11.98 & 12.89 & 0.99 & 10.99 & 0.04 & 0.0004 & 0.039 \\
\hline $900{ }^{\circ} \mathrm{C}$ & 15.46 & 2.88 & 0.64 & 6.47 & 12.69 & 0.45 & 6.02 & 0.02 & 0.0002 & 0.020 \\
\hline $1000{ }^{\circ} \mathrm{C}$ & 62.12 & 2.79 & 0.88 & 1.46 & 6.15 & 0.04 & 1.42 & 0.002 & 0.00002 & 0.002 \\
\hline
\end{tabular}




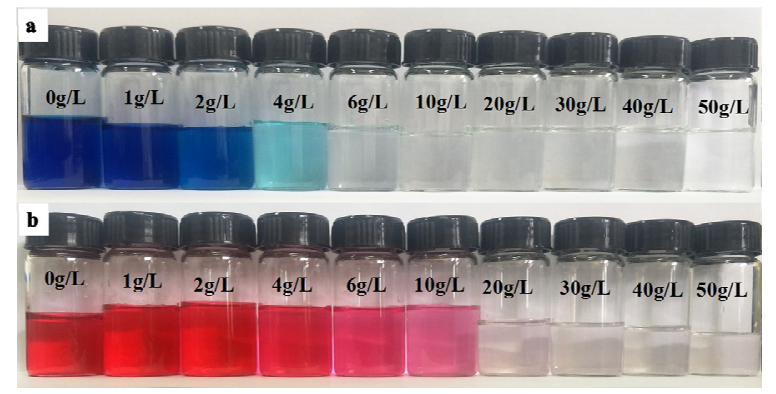

Fig. 9 Photographs of (a) MB and (b) BF solutions treated using different microsphere dosages.

respectively. Meanwhile, the MB removal effciency reached $100 \%$ for the microspheres treated at 800 and $900{ }^{\circ} \mathrm{C}$. As all the microsphere dosage increased from 20 to $50 \mathrm{~g} / \mathrm{L}$, the adsorption capacity decreased slowly and tended to achieve balance. Thus further increase in microsphere mass did not affect the removal rate, it may be controlled by the unavailability of adsorbate sites which could be saturated by the MB molecules $[33,34]$. As for the BF, at lower adsorbent dosage $(<10 \mathrm{~g} / \mathrm{L})$, there was a sharp increase in removal efficiency, which was because of more adsorption sites [33-35]. At higher adsorbent dosage ( $>10 \mathrm{~g} / \mathrm{L})$, the adsorbent dosage had little effect on the removal of BF dyes. The $\mathrm{MB}$ and BF removal efficiency reached $100 \%$ and $99.9 \%$ for the microspheres with the dosage of $20 \mathrm{~g} / \mathrm{L}$ calcined at $800{ }^{\circ} \mathrm{C}$, respectively.

During the process of adsorption, the adsorption efficiency is determined by adsorption time and adsorption rate, which directly determines the time and cost of wastewater treatment. The contact time is also an important influencing factor for dye adsorption.
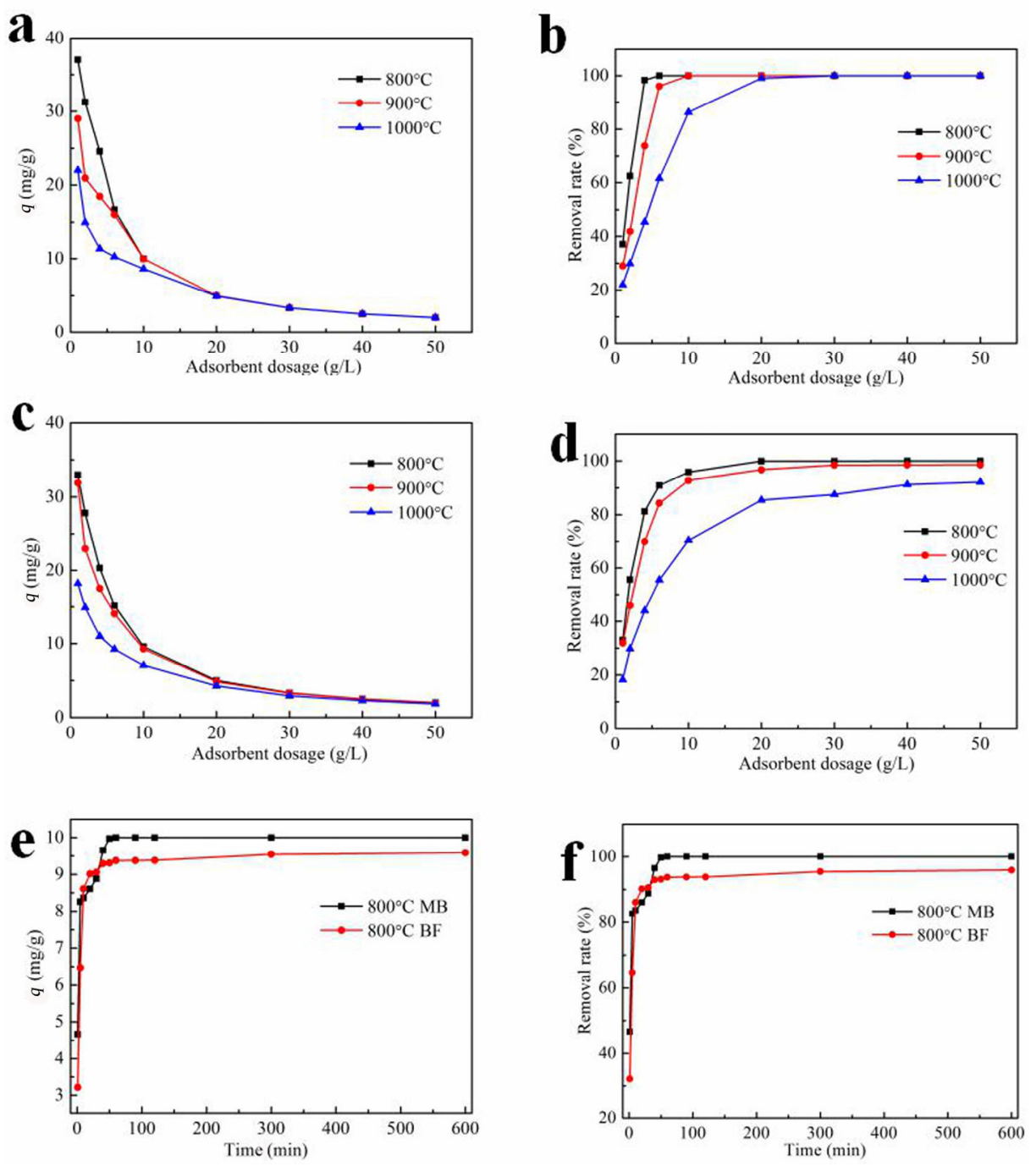

Fig. 10 Effects of operational parameters on the adsorption capacity and removal efficiency of MB and BF: (a, b) MB, (c, d) BF, and $(e, f)$ contact time. 

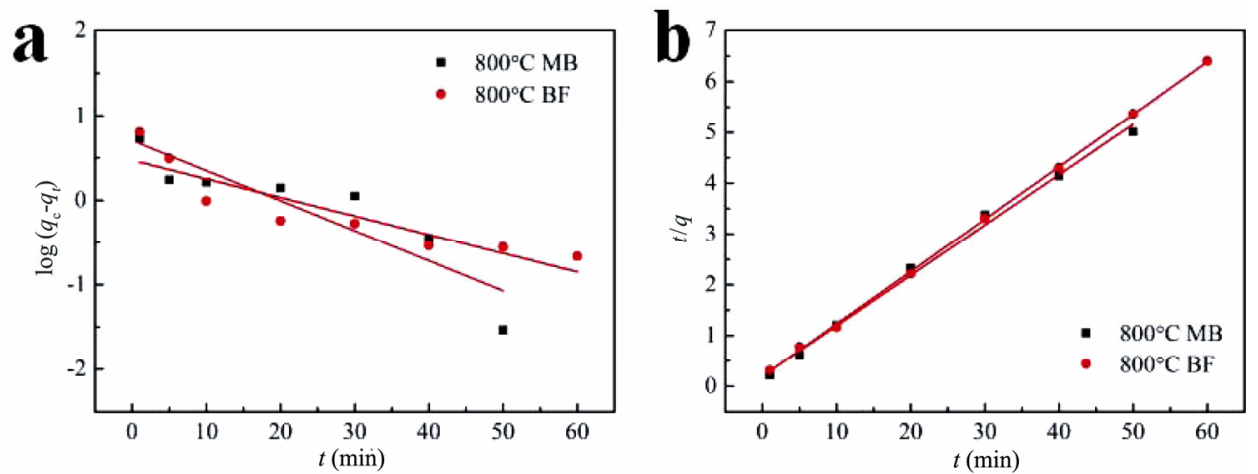

Fig. 11 Kinetic fits for MB and BF adsorption: (a) pseudo-first-order kinetic model, (b) pseudo-second-order kinetic model.

As for the microspheres treated at $800{ }^{\circ} \mathrm{C}$, the influence of contact time on $\mathrm{MB}$ and $\mathrm{BF}$ adsorption capacity and removal efficiency was also shown in Figs. 10(e) and 10(f). The adsorption process could be divided into three stages: when the time is less than $10 \mathrm{~min}$, the removal efficiency increased rapidly; then, the removal efficiency increased steadily with the time reaching 60 min. The removal efficiency of the $\mathrm{MB}$ and $\mathrm{BF}$ reached to $100 \%$ and $93.7 \%$ at $60 \mathrm{~min}$, respectively. As contact time continued to increase $(>60 \mathrm{~min})$, the removal efficiency and adsorption capacity tended to stabilize, which provided that the dye adsorption reached an equilibrium state. Thus, according to the experiments and cost, the proper treated condition of the coal gangue microspheres was $800{ }^{\circ} \mathrm{C}$ for $1 \mathrm{~h}$, and the suitable microsphere dosage value for two dyes was $10 \mathrm{~g} / \mathrm{L}$, which was chosen for the next experiments.

\subsubsection{Adsorption kinetics}

The adsorption kinetic mechanisms for gangue microspheres of $\mathrm{MB}$ and $\mathrm{BF}$ were studied by pseudofirst-order (Eq. (7)) and pseudo-second-order kinetic models (Eq. (8)) [33,34]:

$$
\begin{gathered}
\log \left(q_{\mathrm{e}}-q_{t}\right)=\log q_{\mathrm{e}}-\frac{k_{1}}{2.303} t \\
\frac{t}{q_{t}}=\frac{1}{k_{2} q_{\mathrm{e}}^{2}}+\frac{t}{q_{\mathrm{e}}}
\end{gathered}
$$

In Eqs. (7) and (8), $q_{t}$ and $q_{\mathrm{e}}(\mathrm{mg} / \mathrm{g})$ presented the adsorption capacities of microspheres at time $t$ and equilibrium, respectively; $k_{1}\left(\mathrm{~min}^{-1}\right)$ and $k_{2}(\mathrm{~g} /(\mathrm{mg} \cdot \mathrm{min}))$ were the pseudo-first-order and second-order kinetic rate constants, respectively. The parameters $k_{1}, k_{2}$, and $q_{\mathrm{e}}$ can be calculated from the slope and intercept of the plots of $\log \left(q_{\mathrm{e}}-q_{t}\right)$ and $t / q_{t}$ versus $t$, respectively, as shown in Fig. 11 and Table 3.

The correlation coefficient $\left(R^{2}\right)$ values for the $\mathrm{MB}$
Table 3 Kinetics and isotherm parameters for adsoption of gangue microspheres

\begin{tabular}{cccc}
\hline & Parameter & Methylene blue & Basic fuchsin \\
\hline \multirow{2}{*}{$\begin{array}{c}\text { Pseudo-first-order } \\
\text { model }\end{array}$} & $k_{1}\left(\mathrm{~min}^{-1}\right)$ & 0.0818 & 0.0506 \\
& $q_{\mathrm{e}}(\mathrm{mg} / \mathrm{g})$ & 5.0611 & 2.9562 \\
& $R^{2}$ & 0.7810 & 0.7902 \\
$\begin{array}{c}\text { Pseudo-second- } \\
\text { order model }\end{array}$ & $k_{2}(\mathrm{~g} /(\mathrm{mg} \cdot \mathrm{min}))$ & 0.0491 & 0.0556 \\
& $q_{\mathrm{e}}(\mathrm{mg} / \mathrm{g})$ & 10.0766 & 9.6796 \\
& $R^{2}$ & 0.9941 & 0.9996 \\
\hline \multirow{4}{*}{$\begin{array}{c}\text { Langmuir isotherm } \\
k_{\mathrm{L}}(\mathrm{L} / \mathrm{mg})\end{array}$} & 0.2348 & 0.1825 \\
& $q_{\max }(\mathrm{mg} / \mathrm{g})$ & 30.0120 & 24.1604 \\
& $R^{2}$ & 0.9895 & 0.9905 \\
$\begin{array}{c}\text { Freundlich } \\
\text { isotherm }\end{array}$ & $k_{\mathrm{F}}(\mathrm{L} / \mathrm{mg})$ & 17.7398 & 6.7709 \\
& $1 / n$ & 0.1022 & 0.3186 \\
\hline
\end{tabular}

and $\mathrm{BF}$ of the pseudo-first-order model were lower than those of the pseudo-second-order kinetic model (Table 3). Besides, the calculated $q_{\mathrm{e}}$ values of pseudosecond-order kinetic model (MB: $10.0766 \mathrm{mg} / \mathrm{g}, \mathrm{BF}$ : $9.6796 \mathrm{mg} / \mathrm{g}$ ) were closer to the experimental $q_{\mathrm{e}}$ values (MB: $10.0000 \mathrm{mg} / \mathrm{g}$, BF: $9.5888 \mathrm{mg} / \mathrm{g}$ ). Thus, the absorption of $\mathrm{MB}$ and $\mathrm{BF}$ of the microspheres seemed to be described better by the pseudo-second-order kinetic model.

\subsubsection{Adsorption isotherm and mechanism}

Figure 12 shows the adsorption isotherms of MB and $\mathrm{BF}$ of the microspheres. The selection of an isotherm model depends on the nature and type of the system [33,34]. Herein, the Langmuir model (Eq. (9)) and Freundlich model (Eq. (10)) were used to describe the adsorption equilibrium of the microspheres, expressed as

$$
\frac{c_{\mathrm{e}}}{q_{\mathrm{e}}}=\frac{c_{\mathrm{e}}}{q_{\max }}+\frac{1}{q_{\max } k_{\mathrm{L}}}
$$



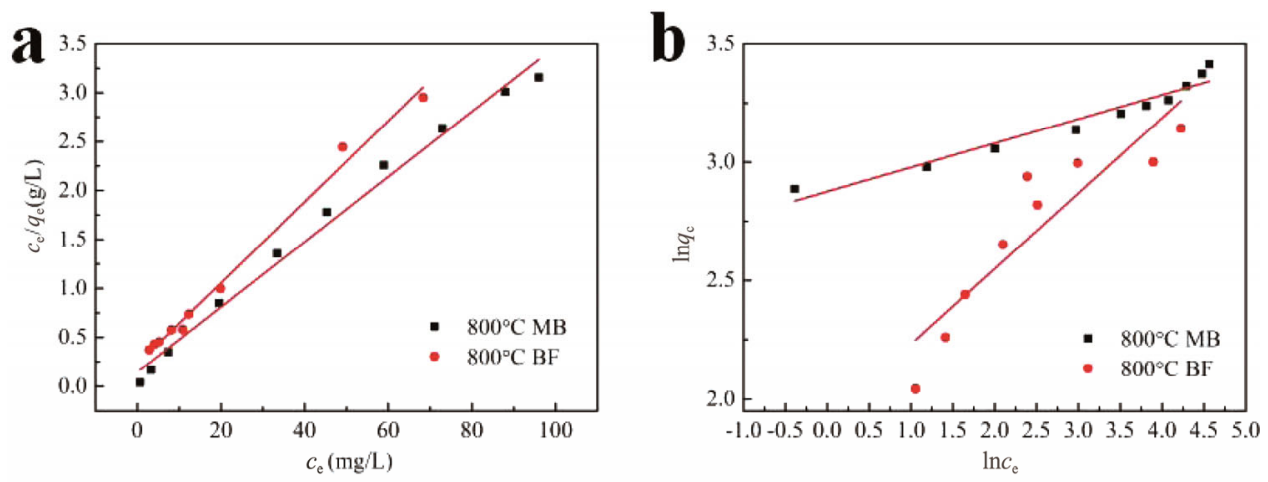

Fig. 12 Linear fits of the isotherm models for MB and BF adsorption: (a) Langmuir, (b) Freundich.

$$
\ln q_{\mathrm{e}}=\ln k_{\mathrm{F}}+\frac{1}{n} \ln c_{\mathrm{e}}
$$

where $c_{\mathrm{e}}(\mathrm{mg} / \mathrm{L})$ is the equilibrium concentration of the $\mathrm{MB}$ and $\mathrm{BF}$ solutions, $q_{\mathrm{e}}(\mathrm{mg} / \mathrm{g})$ and $q_{\max }(\mathrm{mg} / \mathrm{g})$ are the equilibrium adsorption capacity and maximum monolayer adsorption capacity, respectively, $k_{\mathrm{L}}(\mathrm{L} / \mathrm{mg})$ and $k_{\mathrm{F}}(\mathrm{L} / \mathrm{mg})$ are the Langmuir and Freundich constants, respectively, and $n$ is the Freundlich intensity factor. The values of all the adsorption isotherm parameters of $\mathrm{MB}$ and $\mathrm{BF}$ are listed in Table 3.

For the MB solution, both the Langmuir and Freundlich isotherm could describe the adsorption well, especially for the Langmuir model. The adsorption of BF matched well with the Langmuir model. Thus, the adsorption process of dyes could occur on a uniform surface by monolayer adsorption [33,35]. The maximum adsorption capacity of $\mathrm{MB}$ and $\mathrm{BF}$ was calculated 30.0120 and $24.1604 \mathrm{mg} / \mathrm{g}$, respectively. Attributing to the increase of pore volume and specific surface area, the gangue itself has good adsorption. Compared with pure gangue powder, the gangue microspheres have low cost, high porosity, high strength, and robust structure, which make it an ideal candidate for filtration and adsorption in textile wastewater effectively.

Adsorption is a complicated process; less work has been carried out in this direction especially to understand the mechanism of adsorption. Attributing to high pore volume and specific surface area of the microspheres, physical adsorption plays a major role during the adsorption process. As for the microspheres, the presence of $-\mathrm{OH}\left(3661 \mathrm{~cm}^{-1}\right)$ could lead to a hydrophilic nature of the surface and acted as anchoring sites for dye molecules (Fig. 5) [36]. The crystal kaolin contains many $\mathrm{SiO}_{2}$ and $\mathrm{Al}_{2} \mathrm{O}_{3}$ tetrahedra, edges carried both $\mathrm{SiOH}$ and $\mathrm{AlOH}$ sites, and surfaces were believed to carry a constant structural negative charge, which may attract interaction with the cationic dyes [37-39]. Based on the above results, the high performance in the adsorption possibly resulted from multiple adsorption mechanisms including physical adsorption, hydrogen bonding, and electrostatic interactions between dyes and gangue microspheres.

\subsubsection{Material recovery}

The regeneration properties of the adsorbents are significant economic aspects to estimate the quality of the materials. Since high temperature calcinations in air can decompose the organic dyes on surfaces or in pores of kaolin [36], the microspheres were desorbed at $800{ }^{\circ} \mathrm{C}$ holding $2 \mathrm{~h}$ for reuse. The regeneration properties of the microspheres were conducted repeatedly by dropping $0.5 \mathrm{~g}$ microspheres into $50 \mathrm{~mL}(100 \mathrm{mg} / \mathrm{L})$ dye solutions. Three cycles of adsorption-desorption were carried out and the relative ratio of adsorption capacity $\left(q_{\mathrm{e}, n} / q_{\mathrm{e}, 0}\right)$ was calculated. As shown in Fig. 13, $q_{\mathrm{e}, n} / q_{\mathrm{e}, 0}$ of microspheres still reached $\sim 97 \%$ after three cycles, which indicated that the microspheres were excellent of cyclic regeneration.

Table 4 shows adsorption capacities of new adsorbents.

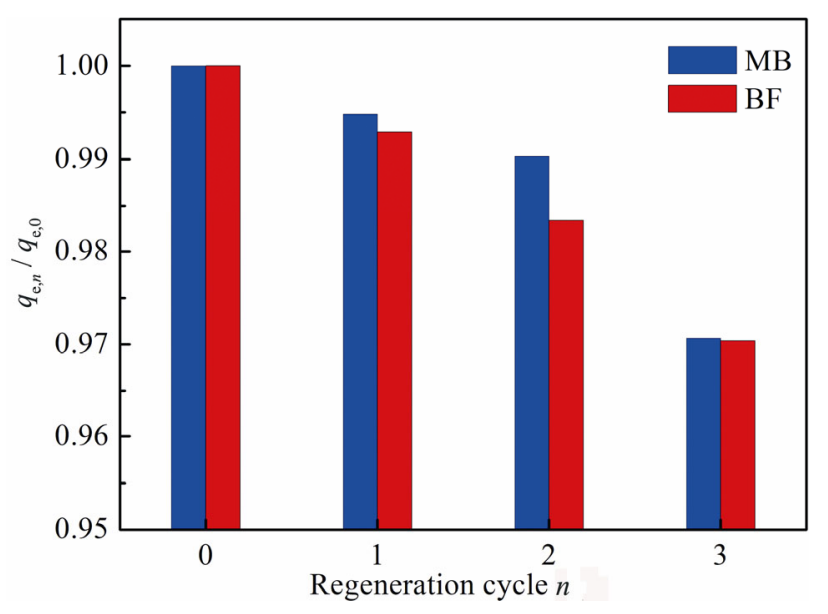

Fig. 13 Regeneration properties of the microspheres. 
Table 4 Comparison of the adsorption capacities of some new adsorbents for removal dyes

\begin{tabular}{llcc}
\hline \multicolumn{1}{c}{ Adsorbent } & \multicolumn{1}{c}{ Dye } & $q_{\max }(\mathrm{mg} / \mathrm{g})$ & Reference \\
\hline Gangue microspheres & Methylene blue & 30.0120 & This work \\
Gangue microspheres & Basic fuchsin & 24.1604 & This work \\
Nano-Fe $_{3} \mathrm{O}_{4}$ & Methylene blue & $6-35$ & {$[40]$} \\
Modified pumice stone & Methylene blue & 15.87 & {$[41]$} \\
Zeolite & Methylene blue & 23.6 & {$[42]$} \\
Carbon nanotubes & Methylene blue & 109.31 & {$[43]$} \\
Calcined mussel shell & Basic fuchsin & 141.65 & {$[44]$} \\
Biogenic apatite & Basic fuchsin & 16.24 & {$[45]$} \\
Malted sorghum mash & Basic fuchsin & 58.48 & {$[46]$} \\
\hline
\end{tabular}

As can be seen, the adsorption capacity of gangue microspheres was $>20 \mathrm{mg} / \mathrm{g}$, which suggested it has potential applications as a good adsorbent compared with other adsorbents. Thus, the gangue microspheres have potential applications in dye wastewater filtration and adsorption treatments.

\section{Conclusions}

In the present study, low-cost porous microspheres from waste gangue were provided and the effects of calcination temperature on the microstructure evolution and adsorption properties were investigated systematically.

(1) The porous microspheres could be prepared by simple spray drying and subsequent calcination. The phase of the microspheres kept kaolinite after treated at 800 and $900{ }^{\circ} \mathrm{C}$ for $1 \mathrm{~h}$ and transformed into mullite at $1000{ }^{\circ} \mathrm{C}$. The microspheres were spherical, with some mesopores both on the surface and in the middle. The BET specific surface area of the calcined microspheres were $11.98\left(800{ }^{\circ} \mathrm{C}\right), 6.47\left(900{ }^{\circ} \mathrm{C}\right)$, and $1.46 \mathrm{~m}^{2} / \mathrm{g}$ $\left(1000{ }^{\circ} \mathrm{C}\right)$, which was decreased with the calcination temperature.

(2) The microspheres calcined at $800{ }^{\circ} \mathrm{C}$ shows more adsorption capacity and removal efficiency for dyes than the ones calcined at higher temperatures. When the dosage increased to $20 \mathrm{~g} / \mathrm{L}$, the $\mathrm{MB}$ and $\mathrm{BF}$ removal efficiency reached $100 \%$ and $99.9 \%$ for the microspheres calcined at $800{ }^{\circ} \mathrm{C}$, respectively. The adsorption process of dyes followed the pseudosecond-order kinetic model. The experiment data of absorption of two dyes fit better with the Langmuir equation. Physical adsorption, hydrogen bonding, and electrostatic interactions between dyes and gangue microspheres contributed to the adsorption process. The low-cost porous microsphere also has excellent of cyclic regeneration properties, which suggested it has potential applications in wastewater filtration and adsorption treatment.

\section{Acknowledgements}

This project was funded by China Postdoctoral Science Foundation (Grant No. 2017M610085) and National Natural Science Foundation of China (NSFC, Nos. 51702184 and 51572140).

\section{References}

[1] Green DJ. Fabrication and mechanical properties of lightweight ceramics produced by sintering of hollow spheres. J Am Ceram Soc 1985, 68: 403-409.

[2] Cochran JK. Ceramic hollow spheres and their applications. Curr Opin Solid St M 1998, 3: 474-479.

[3] Cheow WS, Li S, Hadinoto K. Spray drying formulation of hollow spherical aggregates of silica nanoparticles by experimental design. Chem Eng Res Des 2010, 88: 673685.

[4] Liu M-P, Luo Y-P, Xu L, et al. Hollow-structured Si/SiC@C nanospheres as highly active catalysts for cycloaddition of epoxides with $\mathrm{CO}_{2}$ under mild conditions. Dalton Trans 2016, 45: 2369-2373.

[5] Yang J, Cai K, Xi X, et al. Process and device for the preparation of hollow microspheres comprising centrifugal atomization. U.S. Patent 8,845,936. 2014.

[6] Gonzenbach UT, Studart AR, Tervoort E, et al. Macroporous ceramics from particle-stabilized wet foams. $J$ Am Ceram Soc 2007, 90: 16-22.

[7] Leib EW, Vainio U, Pasquarelli RM, et al. Synthesis and thermal stability of zirconia and yttria-stabilized zirconia microspheres. J Colloid Interface Sci 2015, 448: 582-592.

[8] Schmitt ML, Shelby JE, Hall MM. Preparation of hollow glass microspheres from sol-gel derived glass for application in hydrogen gas storage. J Non-Cryst Solids 2006, 352: 626-631.

[9] Sun X, Liu J, Li Y. Use of carbonaceous polysaccharide microspheres as templates for fabricating metal oxide hollow spheres. Chem Eur J 2006, 12: 2039-2047.

[10] Noh S-C, Lee S-Y, Kim S, et al. Synthesis of thermally stable porous $\mathrm{SiC}$ hollow spheres and control of the shell thickness. Microporous Mesoporous Mater 2014, 199: 11-17.

[11] Qu Y-N, Xu J, Su Z-G, et al. Lightweight and high-strength glass foams prepared by a novel green spheres hollowing technique. Ceram Int 2016, 42: 2370-2377.

[12] Qi F, Xu X, Xu J, et al. A novel way to prepare hollow sphere ceramics. J Am Ceram Soc 2014, 97: 3341-3347.

[13] Li L, Zhang Y, Zhang Y, et al. The thermal activation process of coal gangue selected from Zhungeer in China. $J$ Therm Anal Calorim 2016, 126: 1559-1566.

[14] Jabłońska B, Kityk AV, Busch M, et al. The structural and surface properties of natural and modified coal gangue. $J$ 
Environ Manage 2017, 190: 80-90.

[15] Querol X, Izquierdo M, Monfort E, et al. Environmental characterization of burnt coal gangue banks at Yangquan, Shanxi Province, China. Int J Coal Geol 2008, 75: 93-104.

[16] Zhang Y, Xu L, Seetharaman S, et al. Effects of chemistry and mineral on structural evolution and chemical reactivity of coal gangue during calcination: Towards efficient utilization. Mater Struct 2015, 48: 2779-2793.

[17] Cao Z, Cao Y, Dong H, et al. Effect of calcination condition on the microstructure and pozzolanic activity of calcined coal gangue. Int J Miner Process 2016, 146: 23-28.

[18] Qian T, Li J. Synthesis of Na-A zeolite from coal gangue with the in-situ crystallization technique. Adv Powder Technol 2015, 26: 98-104.

[19] Querol X, Plana F, Alastuey A, et al. Synthesis of Na-zeolites from fly ash. Fuel 1997, 76: 793-799.

[20] Ji H, Fang M, Huang Z, et al. Effect of $\mathrm{La}_{2} \mathrm{O}_{3}$, additives on the strength and microstructure of mullite ceramics obtained from coal gangue and $\gamma-\mathrm{Al}_{2} \mathrm{O}_{3}$. Ceram Int 2013, 39: 6841-6846.

[21] Qiu R, Cheng F. Modification of waste coal gangue and its application in the removal of $\mathrm{Mn}^{2+}$ from aqueous solution. Water Sci Technol 2016, 74: 524-534.

[22] Alkan M, Kalay B, Doğan M, et al. Removal of copper ions from aqueous solutions by kaolinite and batch design. $J$ Hazard Mater 2008, 153: 867-876.

[23] Unuabonah EI, Adebowale KO, Dawodu FA. Equilibrium, kinetic and sorber design studies on the adsorption of Aniline blue dye by sodium tetraborate-modified Kaolinite clay adsorbent. J Hazard Mater 2008, 157: 397-409.

[24] Khan TA, Khan EA, Shahjahan. Removal of basic dyes from aqueous solution by adsorption onto binary ironmanganese oxide coated kaolinite: Non-linear isotherm and kinetics modeling. Appl Clay Sci 2015, 107: 70-77.

[25] Yin J, Pei M, He Y, et al. Hydrothermal and activated synthesis of adsorbent montmorillonite supported porous carbon nanospheres for removal of methylene blue from waste water. RSC Adv 2015, 5: 89839-89847.

[26] Li M, Wang C, O'Connell M J, et al. Carbon nanosphere adsorbents for removal of arsenate and selenate from water. Environ Sci Nano 2015, 2: 245-250.

[27] Tan W-F, Wang L-A, Huang C. Environmental effects of coal gangue and its utilization. Energ Source Part A 2016, 38: 3716-3721.

[28] Li Y, Yao Y, Liu X, et al. Improvement on pozzolanic reactivity of coal gangue by integrated thermal and chemical activation. Fuel 2013, 109: 527-533.

[29] Cliff TJ, Jessica EK, David LB, et al. Low-temperature FTIR study of kaolin-group minerals. Clay Clay Miner 2008, 56: 470-485.

[30] Frost RL. The structure of the kaolinite minerals-a FT-Raman study. Clay Miner 1997, 32: 65-77.

[31] Ma N, Deng Y, Liu W, et al. A one-step synthesis of hollow periodic mesoporous organosilica spheres with radially oriented mesochannels. Chem Commun 2016, 52: 35443547.

[32] Zhou C, Liu G, Yan Z, et al. Transformation behavior of mineral composition and trace elements during coal gangue combustion. Fuel 2012, 97: 644-650.

[33] Li Q, Li Y, Ma X, et al. Filtration and adsorption properties of porous calcium alginate membrane for methylene blue removal from water. Chem Eng J 2017, 316: 623-630.

[34] Hassan AF, Elhadidy H. Production of activated carbons from waste carpets and its application in methylene blue adsorption: Kinetic and thermodynamic studies. J Environ Chem Eng 2017, 5: 955-963.

[35] Du Q, Sun J, Li Y, et al. Highly enhanced adsorption of congo red onto graphene oxide/chitosan fibers by wetchemical etching off silica nanoparticles. Chem Eng J 2014, 245: 99-106.

[36] Vimonses V, Lei S, Jin B, et al. Adsorption of congo red by three Australian kaolins. Appl Clay Sci 2009, 43: 465-472.

[37] Nandi BK, Goswami A, Das AK, et al. Kinetic and equilibrium studies on the adsorption of crystal violet dye using kaolin as an adsorbent. Sep Sci Technol 2008, 43: 1382-1403.

[38] Peyratout C, Donath E, Daehne L. Electrostatic interactions of cationic dyes with negatively charged polyelectrolytes in aqueous solution. $J$ Photoch Photobio A 2001, 142: 51-57.

[39] Huang X-Y, Bu H-T, Jiang G-B, et al. Cross-linked succinyl chitosan as an adsorbent for the removal of Methylene Blue from aqueous solution. Int J Biol Macromol 2011, 49: 643651.

[40] Ali I. New generation adsorbents for water treatment. Chem Rev 2012, 112: 5073-5091.

[41] Derakhshan Z, Baghapour MA, Ranjbar M, et al. Adsorption of methylene blue dye from aqueous solutions by modified pumice stone: Kinetics and equilibrium studies. Health Scope 2013, 2: 136-144.

[42] Jafari-zare F, Habibi-yangjeh A. Competitive adsorption of methylene blue and rhodamine B on natural zeolite: Thermodynamic and kinetic studies. Chin J Chem 2010, 28: 349-356.

[43] Ho Y-S, Malarvizhi R, Sulochana N. Equilibrium isotherm studies of methylene blue adsorption onto activated carbon prepared from Delonix regia pods. J Environ Prot Sci 2009, 3: $111-116$.

[44] Haddad ME. Removal of Basic Fuchsin dye from water using mussel shell biomass waste as an adsorbent: Equilibrium, kinetics, and thermodynamics. Journal of Taibah University for Science 2016, 10: 664-674.

[45] Kizilkaya B. Usage of biogenic apatite (fish bones) on removal of basic fuchsin dye from aqueous solution. $J$ Disper Sci Technol 2012, 33: 1596-1602.

[46] Oyelude EO, Frimpong F, Dawson D. Studies on the removal of basic fuchsin dye from aqueous solution by $\mathrm{HCl}$ treated malted sorghum mash. J Mater Environ Sci 2015, 6: $1126-1136$.

Open Access The articles published in this journal are distributed under the terms of the Creative Commons Attribution 4.0 International License (http://creativecommons.org/licenses/by/4.0/), which permits unrestricted use, distribution, and reproduction in any medium, provided you give appropriate credit to the original author(s) and the source, provide a link to the Creative Commons license, and indicate if changes were made. 